\title{
The Construction of Entrepreneurship Network in Entrepreneurial University-A Case Study of Stanford University
}

\author{
Wei LU', Shan-Shan LI b, ${ }^{\text {, }}$, Hai-Yan YAN ${ }^{c}$ \\ North China Electric Power University, Baoding 071003, Hebei, China \\ ancepulss2010@126.com, 15230270250@126.com, ${ }^{c} 1574309544 @ q q . c o m$
}

Keywords: entrepreneurship education; entrepreneurial university; entrepreneurship network.

\begin{abstract}
In recent years, with more and more attention paid to entrepreneurship education, practices of those famous entrepreneurial universities have aroused public concern, among which includes the entrepreneurship network of Stanford University. It has makes integration of entrepreneurship activities and entrepreneurship education in university, which has set a great example for our universities in China. Entrepreneurship network was an initiative of Stanford University, which can promote the development of innovation and entrepreneurship and provide a driving force for the economy of the local community and even the whole world.
\end{abstract}

\section{Introduction}

When it comes to Silicon Valley, the next thing people typically mention is Stanford University. This is unsurprising given that a recent Stanford study estimated that the university's entrepreneurs have generated revenues of $\$ 2.7$ trillion annually and created 5.4 million jobs. The study found that if Stanford entrepreneurs comprised a country, then it would be ranked as the world's 10th largest economy. Behind the legend of Silicon Valley and great achievements of Stanford entrepreneurship lie the entrepreneurship education of Stanford University and its entrepreneurship network. In order to uncover the secret of Stanford entrepreneurship, this paper has studied the entrepreneurship network of this university.

\section{Background of the Study}

With the number of graduates from universities and colleges rising dramatically, it is more and more difficult for college students to find a job. Facing with the fierce competition in the job market, large quantities of college graduates choose to start their own business instead of becoming an employee in other companies. Under this background, many universities in China try to enhance their entrepreneurship education and practice by learning from some famous American entrepreneurial universities like the MIT and Stanford.

This thesis will give a brief introduction about the development process of entrepreneurship education and entrepreneurial universities in America, discuss the history of Stanford University and its relation with the Silicon Valley, and detail the entrepreneurship network in Stanford, hoping to provide some enlightenment for universities in China to improve the quality of entrepreneurship education and equip their students with better entrepreneurial skills.

\section{Method of the Study}

The method of case study is applied in this research, since case study is quite applicable to the process of understanding a phenomenon, looking for new concepts or ideas, and even suitable to the process of theorizing. This research has strictly followed the general principles, procedures and methods of typical case study, defining two fundamental research problems: What are basic elements of Stanford entrepreneurship network? How do those elements work with each other to promote the entrepreneurship education and entrepreneurship activities in Stanford?

This thesis chose Stanford University as the single case, because Stanford is the first to put forward the concept of entrepreneurship network and choosing typical case is the most common practice in 
case study. During the analytic process, the entrepreneurship network has been split into many parts to study their interconnections.

\section{Entrepreneurship Education in Stanford University}

\section{Development History of American Entrepreneurship Education}

It is believed that entrepreneurship education started in America when Myles Mace taught the first entrepreneurship course - Management of New Enterprises - at Harvard's Business School in February 1947 which drew 188 of 600 second-year MBA students. Since 1980s, entrepreneurship has become one of the fastest growing area in American universities, especially in business schools and engineering schools. In 1994, more than 120,000 American students were taking entrepreneurship or small business courses, and at the start of the new millennium that number is thought to have increased by $50 \%$. According to Jeffry A. Timmons, a famous educator engaged in entrepreneurship education, "in the last 20 years of the 20th century, entrepreneurs and innovators transformed the economy of America and the whole world completely, and 95\% fortune of America was created by entrepreneurs after 1980s". From that first class in 1947, there has emerged more than 100 research centers about entrepreneurship and more than 2200 courses at over 1600 schools in 2005.

Generally speaking, the history of American entrepreneurship education can be divided into three phases:

\section{The Emerging Phase (1876-1947)}

At the beginning of the 19th century, America was still a traditional agricultural country. After the War of 1812, American government enacted Tariff Law in 1816 to protect its domestic industry, and as a result, American industry gained a rapid development during that period and America was transformed into an industrial country.

In 1876, Francis Walker, former President of American Economic Association, came up with the concept of "entrepreneur" in his new book The Wages Question. In 1884, his book Political Economy further extended his model for the entrepreneur. From 1929 to 1933, America experienced the most severe economic crisis. Thanks to the series of recovery efforts and reform bills in the Roosevelt's New Deal, American economy recovered and back to normal. The New Deal supported the development of small businesses and many job opportunities was created through this way. In 1945, Rudolph Weissman's published Small Business and Venture Capital. It is one of the first books to argue for the importance of small business in the economy and the pioneering effort in venture capital. Finally, in February 1947, Myles Mace gave the first MBA entrepreneurship course-Management of New Enterprises - at Harvard, which was regarded as the starting point of entrepreneurship education in America.

\section{The Developmental Phase (1947-1990)}

Before the Great Depression, American oil, railroad, steel and financial markets were under the control of monopoly enterprises. $60 \%$ of the nation's treasure was in the control of minority rich people. In order to eliminate the phenomenon of monopolism and support the development of small businesses, American congress passed Small Business Act in July 1953 and founded Small Business Administration. Through these efforts, the American government wanted to protect the growing of small businesses, encourage free competition and ensure a sound development of the national economy. After the Middle East oil crisis in 1973, American people started to believe in liberalism market economy and American government enacted Economic Recovery Tax Act which reduced the individual income tax of small businesses by $25 \%$ and issued other acts to promote research and innovation in small businesses. During that period, the number of small businesses increased dramatically, from 8.06 million in 1947 to over 15 million, and more than $80 \%$ new jobs were created by newly established small businesses. 
Under this background, the academic cycle started to focus on entrepreneurship, creation and innovation from the perspectives of theory as well as practice. In 1954, the first MBA small business course - Small Business Management - was offered at Stanford. In 1967, the first contemporary MBA entrepreneurship courses introduced at Stanford and New York Universities. These courses focused on wealth-creation vs. firm creation which were regarded as the hallmark of small business courses. After the success of Microsoft, Hewlett Packard, Yahoo!, more and more attention was paid to entrepreneurship education. The first entrepreneurship study center, entrepreneurship activity center, business plan competition, and entrepreneurship education project came into being during this period. American entrepreneurship education formed a scientific and systematic teaching and research system.

\section{The maturity Phase (1990-Now)}

With the deepening of economic globalization and the coming of the era of knowledge-driven economy, technical innovation and management innovation have become key influencing factors that determine the final results of enterprises.

To satisfy the needs of the new era to cultivate more entrepreneurs, American entrepreneurship education stepped into the maturity phase. According to a research by Vesper and Gartner, in 1968, only four universities provided entrepreneurship courses in America. However, that number increased to 370 in 1993 and reached 504 in 2001. More than 60\% people between 18-29 years old expressed their wish to start their own business. By 2005, there has emerged more than 100 research centers about entrepreneurship and more than 2200 courses at over 1600 schools. The contents, teaching methods and goals of entrepreneurship education have become more scientific and the support systems have been further completed.

\section{Connection between Stanford and Silicon Valley}

When people talk about Silicon Valley, the next thing they typically mention is Stanford University. Stanford plays an important role in attracting and retaining talent as well as building a highly skilled workforce in the Silicon Valley region. It is no exaggeration to say that there would be no Silicon Valley without Stanford University. On the other hand, entrepreneurship activities and practices in Silicon Valley has promoted entrepreneurship education of Stanford University.

In 1939, with the encouragement of their professor and mentor, Frederick Terman, Stanford alumni David Packard and William Hewlett established a little electronics company named Hewlett-Packard in a Palo Alto garage. That garage would later be dubbed "the Birthplace of Silicon Valley". In 1951, the Stanford Research Park was established under the proposal of Terman and soon it became both a knowledge center and an incubator for generations of new businesses and products. The success story of Hewlett-Packard attracted world-wide attention, more and more elite entrepreneurs came to here to realize their dreams and start their own businesses, among which include William Shockley who established the Shockley Semiconductor Laboratory in 1955; Robert Noyce and Gordon Moore who founded Fairchild Semiconductor Corp in 1957 and Intel Corporation in 1968, etc. Now, the 700-acre research park has become one of the largest research parks in the country and is thought to be the first technology-focused park. It houses 150 companies in just over 10 million square feet of space. It is a place where startups can find space to work, colleagues to bounce ideas off of, equipment to share and the constant stimulation that comes with new blood from the university.

\section{Stanford Entrepreneurship Education}

On October 1, 1891, Stanford rose from a largely undeveloped agrarian area and dedicated to the formation of "cultured and useful citizens." Stanford University is quite different from those conventional universities in the East. Without the constraint of religion and tradition, Stanford always pursues practical technology. The pioneering spirit and risk-taking culture of old generations in Stanford have made Stanford University one of the best in entrepreneurship education and practice.

In 1954, the first MBA small business course-Small Business Management-was offered at Stanford. In 1967, the first contemporary MBA entrepreneurship courses were introduced at Stanford. 
In 1996, Stanford Business School set up the Entrepreneurship Study Center, and in 1990s, it established E-Commerce \& E-Business Center to adapt to the Internet Age. Now, Stanford has established many research centers related to entrepreneurship and innovation. Apart from the Business School, School of Engineering and School of Medicine in Stanford also offer entrepreneurship courses. In addition, student entrepreneurship groups and entrepreneurship-related activities and competitions have also promoted the entrepreneurship education in Stanford University.

\section{Stanford Entrepreneurship Network(SEN)}

In order to integrate and make the best use of the above entrepreneurship resources within Stanford, Stanford Entrepreneurship Network(SEN) was launched on October 10, 2007. The Stanford Entrepreneurship Network (SEN) is a working group of university programs and student groups offering opportunities for the Stanford community to learn and explore various aspects of entrepreneurship. This section will give a brief introduction about the components of SEN and their interconnections.

\section{Components of SEN and Their Interconnections}

Membership organizations of SEN can be divided into the following eight parts:

1) Graduate School of Business(GSB): Center for Entrepreneurial Studies(CES), Center for Social Innovation(CSI), Stanford Institute for Innovation in Developing Economies(SEED), and Stanford Program on Regions of Innovation and Entrepreneurship(SPRIE);

2) School of Engineering(SOE): Asia Technology Initiative(ATI), Stanford Institute for Electrical and Electronics Engineering(IEEE), Stanford Technology Ventures Program(STVP), US-Asia Technology Management Center(US-ATMC);

3) School of Medicine: Biodesign, School of Medicine Career Center(SoMCC);

4) Humanities: Stanford Social Innovation Review (SSIR);

5)Multidisciplinary organizations: Association of Industry-Minded Stanford Professionals(AIMS), European Entrepreneurship \& Innovation(EE\&I);

6) Office of Technology Licensing (OTL)

7) Stanford affiliated organizations: Stanford Angels \& Entrepreneurs (SA\&E), StartX;

8) Student groups: Asia-Pacific Student Entrepreneurship Society(ASES), Business Association of Stanford Entrepreneurial Students(BASES), Graduate School of Business Entrepreneur Club(GSB E-Club), Society for Entrepreneurship in Latin America(SELA), Stanford Law \& Technology Association(SLATA), Stanford Social Entrepreneurial Students' Association(SENSA), Stanford Venture Capital Club(SVCC), Stanford Law School Entrepreneurship Club(E-Club)

These 22 membership organizations belong to different units, but they could form a powerful network based on their respective functions to promote entrepreneurship education and entrepreneurial practice. Their interactions are shown as below: 


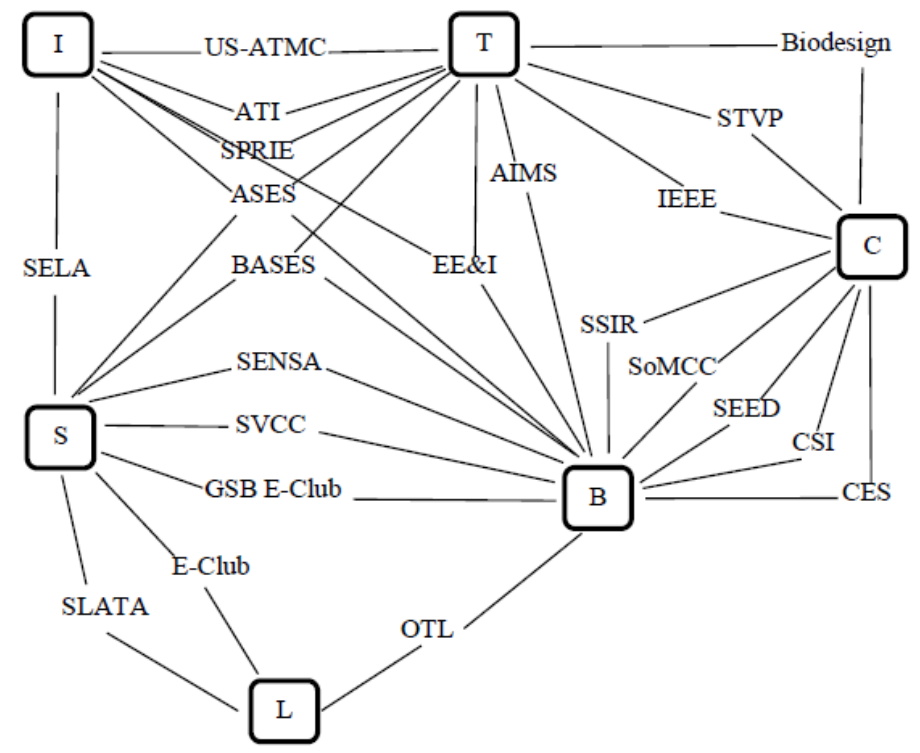

Note: This figure was drown by the author after collecting and sorting out related information on the official website of Stanford Entrepreneurship Network. According to their functions, those organizations in the network are assigned to six function platforms. "B" represents a platform providing business relations and entrepreneurship research resources; "C" refers to education platform which offers entrepreneurship curriculum; "L" means a platform offering legal support or law causes relating to entrepreneurship; "T" represents technical platform which provides technology searching and research; "I" refers to international platform which focuses on international communication about entrepreneurship education and entrepreneurial activities; "S" represents student groups.

\section{Features of SEN}

From the above network, some features of the SEN could be summarized:

1) All of these organizations are interconnected with each other and form an intensive entrepreneurship network.

2) "B" platform, i.e. the platform providing business relations and entrepreneurship research resources, has the most membership organizations, which shows that theoretical researches and research results are core elements of entrepreneurship education and entrepreneurial practice, and also shows that building connections with the market is of great importance to entrepreneurship education.

3) All of the membership organizations on the "C" platform belongs to "B" platform or "T" platform, which represents two major directions of university entrepreneurship education: one is technology-based model, the other is market-demand-based model. Therefore, it is clear that the fundamental purpose of entrepreneurship education in universities is to equip students with the ability to combine technology and business opportunities.

4) Student groups play a significant role in Stanford Entrepreneurship Network. Most of them could establish close business connection with external business environment, and even have the opportunity to take part in international communication with other countries.

\section{Conclusion}

The Stanford Entrepreneurship Network builds a close connection among researchers, teachers, students, alumni and community, and integrates technology education with enterprise entrepreneurship, and consequently achieves the integration among technical research, innovative talents cultivation and economic development through technology transfer. In SEN, "C" platform 
will promote technology development combined with " $\mathrm{T}$ " platform and will stimulate researchers entrepreneurial aspirations through the connection with "B" platform. "L" platform and "S" platform offer supports and incubator for startups. Through international communication and entrepreneurial practice, the whole entrepreneurship process would be improved and entrepreneurship ecosystem in Stanford would be promoted, which ensures a sustainable development of entrepreneurship education and entrepreneurial activities in Stanford University and offers a great example for us to follow.

\section{References}

[1] Charles E. Eesley\&William F. Miller. Impact: Stanford University's Economic Impact Innovation and Entrepreneurship[R]. California: Stanford University, 2012.

[2] http://www.gsb.stanford.edu/faculty-research/centers-initiatives/ces

[3] Jerome A. Katz. The chronology and intellectual trajectory of American entrepreneurship education 1876-1999[J]. Journal of Business Venturing, 2003(18):283-300.

[4] Shi Guanqun et al. The Innovation-entrepreneurship Education and Construction of Entrepreneurship Network in Entrepreneurial University[J]. Studies in Foreign Education, 2009(6):79-83.

[5] Stanford Entrepreneurship Network[EB/OL]. http://sen.stanford.edu/

[6] Universities and Entrepreneurial Ecosystems: Elements of the Stanford-Silicon Valley Success[EB/OL].http://www.kauffmanfellows.org/journal_posts/universities-and-entrepreneurial-ec osystems-stanford-silicon-valley-success/ 